\title{
THRIVING IN MONO- AND MULTICULTURAL ORGANIZATIONAL CONTEXTS
}

\author{
Małgorzata Rozkwitalska*
}

\begin{abstract}
Background. Thriving, composed of learning and vitality produces many positive outcomes for organizations. Yet, there is a lack of studies on thriving which is embedded in social interactions that juxtapose the two types of organizational contexts, i.e. mono- with multicultural ones.
\end{abstract}

Research aims. The aim of the paper is to compare the level of thriving (i.e. learning and vitality) in mono- and multicultural work contexts. The author posits that the multicultural work environment has unique demands conducive to thriving to a larger extent than the monocultural one.

Methodology. The cross-sectional study was conducted in domestic companies and multinational corporations (MNCs) that represent mono- and multicultural workplaces, respectively. The samples comprised 259 employees having only monocultural interactions and 238 individuals involved in intercultural interactions.

Key findings. The research reveals that the subjects employed in the multicultural organizations experienced a higher level of thriving than those working in the monocultural ones. The results support the notion that social contacts, including intercultural interactions, are needed to trigger thriving in organizations. As the paper is concerned with individuals' positive growth, it contributes to the Positive Organizational Scholarship studies.

Keywords: learning, intercultural interactions, monocultural interactions, vitality, international experience.

\section{INTRODUCTION}

Since thriving, composed of learning and vitality (Spreitzer et al., 2005), produces many positive outcomes for organizations, such as improved innovation (Wallace et al., 2013) and personal growth (Baruch et al., 2014), it attracts attention of scholars. To date, a handful

\footnotetext{
WSB University in Gdańsk. E-mail: mrozkwitalska@wsb.gda.pl
} 
of quantitative studies concerning thriving have been carried out in an organizational context. Nevertheless, there is a lack of studies on thriving which is embedded in social interactions that juxtapose the two types of organizational contexts, i.e. mono- with multicultural ones.

To fill that gap, the author refers to mono- and multicultural organizational contexts while analysing thriving. Consequently, the aim of the study is to compare the level of thriving in mono- and multicultural work contexts. The paper posits that the multicultural workplace has unique demands conducive to thriving to a larger extent than the monocultural one. The cross-sectional study was conducted in domestic companies and multinational corporations (MNCs) that represent mono- and multicultural workplaces respectively. The samples comprised 259 employees having only monocultural interactions and 238 individuals involved in intercultural interactions.

The study broadens the understanding of thriving in various organizational contexts, i.e. mono- vs. multicultural workplaces, and supports that it is a truly socially embedded phenomenon.

The paper first defines the organizational context and its two variations, i.e. mono- and multicultural organizational ones. Subsequently, it briefly refers to the theoretical foundation of the study. Then, the author reviews prior research on thriving to substantiate the hypothesis. She also presents the research findings with details concerning the samples and the method. The last part discusses conclusions, contributions, implications and limitations of the study, while directions for future research are also portrayed.

\section{LITERATURE REVIEW}

\section{Mono- and multicultural organizational context}

The notion of "context" is present in many fields and scholars recommend to include it while conducting research, particularly in organizational studies where contextual effects are critical to an understanding of organizational phenomena (Porter \& Mclaughlin, 2006; Whetten, 2008). Social science defines context as elements around the phenomenon impacting on it, some "explanatory factors associated with higher levels of an analysis than those expressly under investigation" (Whetten, 
2008 , p. 31). Other authors see context as a product of activity and interactions among people (Pimmer et al., 2013).

Scholars use three approaches to analyse context, i.e. 1) rich description; 2) direct observation and analysis of contextual effects; and 3) comparative studies (Whetten, 2008). This research applies comparative studies approach as it examines and juxtaposes thriving in mono- and multicultural organizational contexts. Likewise the general perception of context, the author refers the organizational context to the peculiarities of an organization where the phenomenon occurs since it influences its dynamics and persists beyond its life span. It is also seen as an environment of interactions, nevertheless something more than merely the surroundings where interactions exist (Klimkeit, 2013).

In this research, the author compares mono- and multicultural organizational contexts while analysing thriving. The properties of the multicultural organizational contexts are based on the features of a multicultural organization as identified in other studies whereas the peculiarities of a monocultural organization are concluded as the opposite to the former. Lauring and Selmer (2011) imply that a multicultural organization employs a high percentage of different nationalities. According to Adler and Gundersen (2007) such an organization is globally dispersed, i.e. its operations are geographically spread in various countries, and perceived as multicultural as individuals from different countries interact with one another. Consequently, the employees of a multicultural organization represent more than one national culture and usually adopt an official language to facilitate communication among them. A multicultural workplace is also provided since culturally diverse people interact with one another to accomplish their tasks. MNCs with their subsidiaries in various locations can be an example of multicultural organizations.

In previous studies, MNCs are portrayed as organizations with a unique work environment, featuring specific, challenging job demands (Darawong \& Igel, 2012; Hennart, 2010; Rozkwitalska \& Basinska, 2015a). Cultural differences and a language diversity encountered by MNCs' staff have been frequently considered as barriers in prior research (Rivera-Vazquez et al., 2009; Stahl et al., 2009; Stahl \& Tung, 2014). Therefore, their people are expected to adjust to cultural diversity and communicate in the corporate language (Darawong \& Igel, 2012; Lauring \& Klitmøller, 2015; Rozkwitalska \& Basinska, 2015a). Such 
specific job resources as, e.g., language and cross-cultural trainings, IT-enabled technology for dispersed teams, core values, relocation policy, etc., are offered by MNCs to balance their job demands and help their staff to attain the company goals (Rozkwitalska \& Basinska, 2015a).

As the opposite, in a monocultural organization, individuals mainly from the country it operates in are employed. Even if it hires some foreigners, their number is marginal. Moreover, once they enter the organization, they are expected to adopt the organizational values of the majority and communicate in their language (Janssens \& Zanoni, 2014). Global dispersion is not a feature of a monocultural organization since it is mainly focused on its domestic market. As a result, the dominant type of its employees' social interactions is the one introduced by their own national culture and monocultural features. Multiculturalism is therefore not a trait of a monocultural organization. Domestic enterprises, regardless of their size, should usually match the above description (Adler, 1983).

\section{The theoretical background and prior research}

The concept of thriving is rooted in a socially embedded model of thriving (Porath et al., 2012; Spreitzer et al., 2005), which underlines that social interactions create the conducive environment for it. In view of this model, thriving is reflected in two conscious psychological states, i.e. vitality and learning, which capture both the affective (vitality) and the cognitive (learning) aspects of personal growth. Vitality is usually described as aliveness and energy, whereas learning refers to knowledge and skills that a person acquires. Both psychological states require social interactions as vitality is supported by relational connections with other people, and learning is facilitated by social interactions within which people execute their tasks, talk about them or observe their peers at work (Porath et al., 2012; Spreitzer \& Sutcliffe, 2007).

Although thriving attracts scientific inquiry, to date, only a handful of quantitative studies have analyzed it in an organizational context. In addition, there is a lack of studies on thriving embedded in social interactions that juxtapose various types of organizational contexts, i.e. mono- vs. multicultural ones.

So far, various researchers have explored the antecedents of thriving and studied its outcomes (e.g. Abid et al., 2016; Jiang, 2017; Niessen et al., 2012), whereas the others have treated thriving as moderators 
between the antecedents and the outcomes (e.g. Paterson et al., 2014; Wallace et al., 2013). Generally, prior studies perceive thriving as a positive phenomenon from both the individual and organizational perspectives (e.g. Jiang, 2017; Ren et al., 2015; Rozkwitalska \& Basinska, 2016a). Additionally, Porath et al. (2012) imply that thriving is contingent on the work context in which it is rooted.

Considering the aim of this research, there are several works which refer to social interactions and thriving. For instance, the research by Niessen et al. (2012) posit that thriving is strongly embedded socially. Similarly, Carmeli and Russo (2015) highlight the importance of a positive social relation for supporting thriving. The studies by Rozkwitalska and Basinska (2015b, 2016a, 2016b) investigate thriving in intercultural interactions and reveal that the learning component of thriving is particularly vivid in a multicultural workplace of MNCs. Moreover, thriving is related to satisfaction with work in such an environment. The conceptual paper by Rozkwitalska (2016) argues that intercultural interactions may leave more room for thriving than other types of social interactions among people.

Taking the above into account, the author assumes that the organizational context is of crucial significance while thriving is considered. Furthermore, the prevailing type of social interactions depends on the organizational contexts (mono- vs. multicultural ones). Accordingly, she posits that various types of social interactions may trigger thriving, including monocultural ones, i.e. with others from the same cultural group, and intercultural interactions, i.e. with people who represent different cultures. Nevertheless, each type of social interactions creates a unique environment for thriving. Therefore, the author intends to examine whether in the multicultural organizational context of $\mathrm{MNC}$, where people are engaged in intercultural interactions, the level of thriving is different from the level experienced by individuals in a monocultural workplace. Specifically, the study assumes that multicultural organizational contexts may support thriving better, mainly through the learning component that is particularly enhanced in intercultural interactions (Rozkwitalska \& Basinska, 2015b, 2016a; Rozkwitalska, 2016). Thus, the following hypothesis will be tested: The level of thriving experienced by individuals in multicultural work environments is higher than the level of thriving experienced by individuals in a monocultural one. 


\section{RESEARCH METHODOLOGY}

\section{Method and instrument}

The study took a cross-sectional design and was carried out between the years 2015 and 2017. Two samples selected non-randomly, i.e. Sample 1 and Sample 2, represent multicultural organizations with their multicultural work environments and monocultural organizations with their monocultural work environment, respectively.

The statistical analysis included estimation of the descriptive statistics and Pearson correlation coefficients. Furthermore, independent $t$-tests were applied to examine the differences between thriving in both organizational contexts. The effect sizes were also calculated on the basis of Cohen's d coefficient (the results around 0.2, 0.5 and 0.8 indicate small, medium and large effect sizes, respectively, see Cohen, 1988).

Basing on the socially embedded model of thriving at work, it was separately assessed with regard to its two components, namely learning and vitality. In order to measure learning, a 5-item scale by Vandewalle (1997) was applied. Cronbach's alpha were .87 in the multicultural organizations and .84 in the monocultural ones. Vitality was measured as vigor, which can be used as an indicator of vitality. The 3-item subscale of Utrecht Work Engagement Scale (Schaufeli et al., 2006) was applied. Cronbach's alpha were .89 in the multicultural organizations and .84 in the monocultural ones.

The study also included control variables such as job tenure and international experience. The index of international experience ranges from 0 - a lack of international experience, to 1 - the highest level of international experience (see Rozkwitalska \& Basinska, 2016a for details how it is calculated).

\section{Participants}

Sample 1 was composed of individuals employed in subsidiaries of the MNCs whose job demands include involvement in intercultural interactions, while Sample 2 concerns individuals hired in domestic enterprises whose job demands include only monocultural interactions. A subject was added to Sample 1 if s/he answered yes to the following 
questions: "At work, I contact with foreigners (e.g. peers, contractors)"; "I work for a multinational corporation, i.e. a company with foreign affiliates", and to Sample 2 if the answers were no. There were two types of questionnaires, one distributed to the MNCs and the other one to the domestic companies.

Sample 1 counted 238 respondents with an average age of 35 (SD $=8.4$; range: $20-64)$ and an average tenure of 6.2 years $(\mathrm{SD}=5.6$; range: $0.5-39$ years). Concerning other demographics, there were 116 women (49\%) in the sample and 92 respondents (39\%) holding managerial positions. The respondents represented various organizational units, while their average level of international experience was 0.59 $(\mathrm{SD}=0.21$, range $0-0.86)$ (see Table 1$)$.

Sample 2 consisted of 259 participants with average age of 38 ( $\mathrm{SD}=10.4$; range: $19-64)$ and with an average tenure of 10.0 years ( $\mathrm{SD}=10.1$; range: $0.5-49$ years). Concerning other demographics, there were 170 women (66\%) and 54 respondents (21\%) holding managerial positions. Likewise Sample 1, the respondents in Sample 2 were from different organizational units and their average level of international experience was $0.23(\mathrm{SD}=0.19$, range $0.14-1)$ (see Table 1$)$.

Table 1. The descriptive statistics of Sample 1 and Sample 2

\begin{tabular}{|l|l|c|c|c|c|c|c|c|}
\hline Sample & \multicolumn{1}{|c|}{ Variable } & $\mathrm{N}$ & $\mathrm{M}$ & $\mathrm{SD}$ & $\begin{array}{c}\text { Mini- } \\
\text { mum }\end{array}$ & $\begin{array}{c}\text { Maxi- } \\
\text { mum }\end{array}$ & $\begin{array}{c}\text { Skew- } \\
\text { ness }\end{array}$ & Kurtosis \\
\hline \multirow{3}{*}{1} & Age & 203 & 34.83 & 8.41 & 20.00 & 64.00 & 0.98 & 0.99 \\
\cline { 2 - 9 } & Job tenure & 232 & 6.23 & 5.60 & 0.20 & 39.00 & 1.85 & 5.59 \\
\cline { 2 - 9 } & $\begin{array}{l}\text { International } \\
\text { experience }\end{array}$ & 238 & 0.59 & 0.21 & 0.14 & 1.00 & -0.20 & -0.50 \\
\hline \multirow{3}{*}{2} & Age & 244 & 38.14 & 10.44 & 19.00 & 64.00 & 0.371 & -0.653 \\
\cline { 2 - 9 } & Job tenure & 246 & 10.12 & 10.13 & 0.50 & 43.00 & 1.240 & 0.706 \\
\cline { 2 - 9 } & $\begin{array}{l}\text { International } \\
\text { experience }\end{array}$ & 259 & 0.23 & 0.19 & 0.00 & 0.86 & 0.75 & 0.19 \\
\hline
\end{tabular}

Note: $\mathrm{M}$ - mean, SD - standard deviation. Incomplete data in the demographic variables accounted for up to $9.4 \%$ and $8.5 \%$ in mono- and multicultural organizations, respectively.

Source: own study.

The student's t-test for the comparison of the two means for the independent samples have revealed that the respondents from Sample 1 have a higher level of international experience than the subjects from Sample $2(t=20, d f=495, p<.001)$. The effect size of the differences in means was large (Cohen's $d=1.81$ ). Moreover, the 
individuals holding managerial positions, regardless of the type of organizations (mono- vs. multicultural ones), had a higher level of international experience than the employees $(M=0.49$ vs. $M=0.37$, $t=4.9, d f=490, p<.001)$, the effect size was moderate (Cohen's $d=$ 0.433). The share of women and men holding managerial positions were similar in both samples, i.e. there were $52 \%$ female managers and $48 \%$ male managers in Sample 1 , and $46 \%$ and $52 \%$ in Sample 2 , respectively.

\section{RESULTS AND DISCUSSION}

\section{The empirical findings}

Table 2 shows that learning and vitality were positively, yet moderately, correlated in both samples. Moreover, job tenure was positively, yet only slightly, related to vitality in Sample 1.

Table 2. The descriptive statistics, the Pearson product-moment correlation coefficients among the study variables

\begin{tabular}{|l|c|c|c|c|c|c|c|c|}
\hline \multirow{2}{*}{ Variables } & \multicolumn{2}{|c|}{$\begin{array}{c}\text { Sample 1 } \\
\mathrm{N}=238\end{array}$} & \multicolumn{2}{c|}{$\begin{array}{c}\text { Sample 2 } \\
\mathrm{N}=259\end{array}$} & \multirow{2}{*}{$(1)$} & \multirow{2}{*}{$(2)$} & \multirow{2}{*}{$(3)$} & \multirow{2}{*}{$(4)$} \\
\cline { 2 - 10 } & $\mathrm{M}$ & $\mathrm{SD}$ & $\mathrm{M}$ & $\mathrm{SD}$ & & & & \\
\hline (1) Learning & 4.69 & 0.76 & 4.33 & 0.80 & & $.35^{* * *}$ & .13 & -.02 \\
\hline (2) Vitality & 3.71 & 1.20 & 3.42 & 1.10 & $.44^{* * *}$ & & -.02 & .11 \\
\hline $\begin{array}{l}\text { (3) International } \\
\text { experience }\end{array}$ & 0.59 & 0.21 & 0.23 & 0.20 & .13 & .11 & & -.15 \\
\hline (4) Job tenure & 6.23 & 5.60 & 10.00 & 10.00 & .08 & $.19^{* * *}$ & .05 & \\
\hline
\end{tabular}

Note. ${ }^{*} p<.01 ; * * p<.01 ; * * * p<.001 ; \mathrm{M}-$ mean; $\mathrm{SD}-$ standard deviation. All the coefficients are standardized. The correlation coefficients for Sample 1 are below diagonal.

Source: own study.

The hypothesis stated in the study predicts that individuals in the multicultural work environment experience a higher level of thriving than individuals in the monocultural one. The empirical findings exhibit that the respondents in both types of organizations witness thriving at work. Being involved in intercultural interactions as well as participating in monocultural interactions were both correlated with learning and vitality (see Table 3). However, the individuals from 
Sample 1 reported greater learning than those in Sample $2\left(_{(495)}=5.19\right.$ $p<.001)$. The effect size of the differences in the means for learning was moderate (Cohen's $d=0.47$ ). Likewise, the subjects from Sample 1 felt more vitality than the respondents from Sample $2\left(_{(493)}=2.84\right.$ $p<.01)$. The effect size of the differences in the means for vitality was small (Cohen's $d=0.26$ ). The above results show that the hypothesis is confirmed. The individuals from the multicultural organizations experienced a higher level of thriving compared to the respondents working in the monocultural organizations.

Table 3. Learning and vitality in Sample 1 and Sample 2

\begin{tabular}{|l|c|c|c|c|c|c|c|c|c|c|c|}
\hline \multirow{2}{*}{ Variables } & \multicolumn{2}{|c|}{$\begin{array}{c}\text { Sample 1 } \\
\mathrm{N}=238\end{array}$} & \multicolumn{2}{|c|}{$\begin{array}{c}\text { Sample 2 } \\
\mathrm{N}=259\end{array}$} & \multirow{2}{*}{$\mathrm{t}$} & $\mathrm{d}$ & $\mathrm{p}$ & $\begin{array}{c}\mathrm{M} 1 \\
-\mathrm{M} 2\end{array}$ & $\begin{array}{c}\text { CI } \\
-95 \%\end{array}$ & $\begin{array}{c}\text { CI } \\
+95 \%\end{array}$ & \multirow{2}{*}{ Cohen's d } \\
\cline { 2 - 13 } & $\mathrm{M}$ & $\mathrm{SD}$ & $\mathrm{M}$ & $\mathrm{SD}$ & & & & & & & \\
\hline Learning & 4.69 & 0.76 & 4.33 & 0.76 & 5.194 & 495 & .000 & 0.36 & .22 & .49 & $0.470^{* *}$ \\
\hline Vitality & 3.71 & 1.20 & 3.42 & 1.08 & 2.839 & 493 & .005 & 0.29 & .09 & .49 & $0.256^{*}$ \\
\hline
\end{tabular}

Note: $\mathrm{M}$ - mean, SD - standard deviation, an effect size measured with Cohen's d coefficient: ** intermediate effect; * small effect.

Source: own study.

\section{Discussion}

The empirical findings have revealed that in both organizational contexts the respondents experience thriving, yet, as it was predicted, the individuals in the multicultural organizations witness a higher level of thriving than the participants from the monocultural organizations. The effect size was specifically meaningful for the cognitive component of thriving, i.e. learning.

These results can be referred to Work Design Growth Model. It argues that people feel energetic and learn when their workplace is abundant in job demands that are challenging, yet not seen as hindrances, and when they are involved in social interactions that include novelty and diversity (Parker, 2017; Raemdonck et al., 2014). MNCs can be seen as organizations that offer such a work environment. It is mainly due to the fact that their workplace creates stimulating challenges and interactions as people need to cooperate with foreigners and, as a result, face cultural differences as a part of their work duties (Rozkwitalska et al., 2017). Moreover, MNCs facilitate execution of job demands by means of the provided resources (Rozkwitalska et al., 
2016). They help employees to reduce job strains and may influence the cognitive appraisal of job demands (Bakker \& Demerouti, 2014; Rozkwitalska, 2017).

The empirical findings have especially exhibited that the differences in the level of learning experienced by the respondents in both organizational contexts were statistically important. This observation can be referred to the previous studies by Rozkwitalska and Basinska (2015b, 2016a), which show that the learning component of thriving is more noticeable than vitality in MNCs. Also other authors (Puck et al., 2008; Stahl et al., 2010) posit that working in MNCs and intercultural interactions are a natural source of learning. It is evident that when people are engaged in intercultural interactions, they learn from one another and achieve personal and professional development. Accordingly, such interactions make their work duties more exciting, interesting and enthusiastic, supporting simultaneously vitality.

\section{CONCLUSIONS}

The author's research supports the notion that thriving is deeply rooted in social interactions at work (Carmeli \& Spreizer, 2009); Niessen et al., 2012; Paterson et al., 2014), yet its level differs with regard to the mono- and multicultural organizational contexts. The latter may stimulate thriving better.

The study's contributions are as follows: 1) it adds to the knowledge of thriving at work in the mono- and multicultural workplaces, consequently, it fills the gap in previous research; 2) it provides evidence that thriving is a truly socially embedded phenomenon since, as the research exhibits, interactions with others at work contribute to thriving; 3) the paper analyses one's positive growth, i.e. thriving, which adds to the Positive Organizational Scholarship and the Positive Organizational Behaviour studies with that respect.

With regard to the practical implications, the research substantiates that social interactions trigger thriving. Therefore, organizations, by a proper job design (e.g. teamwork), should enable frequent interactions with others at work. Moreover, the study suggests that the multicultural organizational setting may stronger enhance thriving than the monocultural one, thus organizations need to enhance intercultural contacts at work. 
The limitations of this study are as follows: 1) the sample included only Poles, the respondents from various MNCs and domestic enterprises, therefore the industry and company contexts were not captured in the data, in addition, there were more women than men in Sample $2 ; 2$ ) generalization of the findings is limited due to a non-probabilistic sampling technic; 3) a cross-sectional design did not allow for scrutinizing the cause-and-effect relationships.

Future research should respond to the aforementioned limitations. Specifically, it is worth examining whether thriving is stronger in multicultural environments of MNCs than in monocultural organizational contexts by implementing a longitudinal design. Finally, a deeper explanation why in a multicultural workplace the level of thriving was higher is needed.

\section{REFERENCES}

Abid, G., Zahra, I. \& Ahmed, A. (2016). Promoting thriving at work and waning turnover intention: A relational perspective. Future Business Journal, 2(2), 127-137.

Adler, N.J. (1983). Cross-cultural management: Issues to be faced. International Studies of Management \& Organizations, 13(1-2), 7-45.

Adler, N.J. \& Gundersen, A. (2007). International Dimensions of Organizational Behavior (5 $5^{\text {th }}$ edition). Mason, Ohio: South Western, International Edition. Retrieved from http://books.google.com/books?id=w_AnUby8L3EC\&pgis=1 (access: 21.05.2012)

Bakker, A. \& Demerouti, E. (2014). Job demands-resources theory. In: P.Y. Chen \& C.L. Cooper (eds.), Work and Wellbeing: Wellbeing: A Complete Reference Guide (pp. 37-64). Chichester, UK: Wiley-Blackwell.

Baruch, Y., Grimland, S. \& Vigoda-Gadot, E. (2014). Professional vitality and career success: Mediation, age and outcomes. European Management Journal, 32(3), 518-527.

Carmeli, A., \& Russo, M. (2015). The power of micro-moves in cultivating regardful relationships: Implications for work-home enrichment and thriving. Human Resource Management Review.

Carmeli, A. \& Spreizer, G.M. (2009). Trust, connectivity and thriving: implications for innovative bahaviors at work. Journal of Creative Behavior, 43, 169-191.

Cohen, J. (1988). Statistical Power Analysis for Behavioral Sciences. Hillsdale, NJ: Erlbaum. 
Darawong, C. \& Igel, B. (2012). Acculturation of local new product development team members in MNC subsidiaries in Thailand. Asia Pacific Journal of Marketing and Logistics, 24(3), 351-371.

Hennart, J.-F. (2010). Theories of the multinational enterprise. In: A. Rugman (ed.), The Oxford Hanbook of International Business ( $2^{\text {nd }}$ edition, pp. 125-145). New York: Oxford University Press.

Janssens, M. \& Zanoni, P. (2014). Alternative diversity management: Organizational practices fostering ethnic equality at work. Scandinavian Journal of Management, 30(3), 317-331.

Jiang, Z. (2017). Proactive personality and career adaptability: The role of thriving at work. Journal of Vocational Behavior, 98, 85-97.

Klimkeit, D. (2013). Organizational context and collaboration on international projects: The case of a professional service firm. International Journal of Project Management, 31(3), 366-377.

Lauring, J. \& Klitmøller, A. (2015). Corporate language-based communication avoidance in MNCs: A multi-sited ethnography approach. Journal of World Business, 50(1), 46-55.

Lauring, J. \& Selmer, J. (2011). Multicultural organizations: common language, knowledge sharing and performance. Personnel Review, 40(3), 324-343.

Niessen, C., Sonnentag, S. \& Sach, F. (2012). Thriving at work - A diary study. Journal of Organizational Behavior, 33(4), 468-487.

Parker, S.K. (2017). Work Design Growth Model: How work characteristics promote learning and development. In: R.A. Noe \& J.E. Ellingson (eds.), Autonomous Learning in the Workplace (SIOP Front, pp. 137-161). New York: Taylor Francis.

Paterson, T.A., Luthans, F. \& Jeung, W. (2014). Thriving at work: Impact of psychological capital and supervisor support. Journal of Organizational Behavior, 35(3), 434-446.

Pimmer, C., Pachler, N. \& Genewein, U. (2013). Contextual dynamics in clinical workplaces: Learning from doctor-doctor consultations. Medical Education, 47(5), 463-475.

Porath, C., Spreitzer, G., Gibson, C. \& Garnett, F.G. (2012). Thriving at work: Toward its measurement, construct validation, and theoretical refinement. Journal of Organizational Behavior, 33(2), 250-275.

Porter, L.W. \& Mclaughlin, G.B. (2006). Leadership and the organizational context: Like the weather? The Leadership Quarterly 17, 17, 559-576.

Puck, J.F., Mohr, A.T. \& Rygl, D. (2008). An empirical analysis of managers' adjustment to working in multi-national project teams in the pipeline and plant construction sector. The International Journal of Human Resource Management, 19(12), 2252-2267. 
Raemdonck, I., Gijbels, D. \& van Groen, W. (2014). The influence of job characteristics and self-directed learning orientation on workplace learning. International Journal of Training and Development, 18(3), 188-203.

Ren, H., Yunlu, D., Shaffer, M. \& Fodchuk, K. (2015). Expatriate success and thriving: the influence of job deprivation and emotional stability. Journal of World Business, 50, 69-78.

Rivera-Vazquez, J.C., Ortiz-Fournier, L.V. \& Flores, F.R. (2009). Overcoming cultural barriers for innovation and knowledge sharing. Journal of Knowledge Management, 13(5), 257-270.

Rozkwitalska, M. (2016). Thriving in intercultural interactions as an antecedent of organizational creativity and innovation. Problemy Zarzadzania, 14(3), 142-154.

Rozkwitalska, M. (2017). Cognition of the multicultural work environment in multinational corporations and intercultural interaction outcomes. In: M. Rozkwitalska, Ł. Sułkowski \& S. Magala (Eds.), Intercultural Interactions in the Multicultural Workplace. Traditional and Positive Organizational Scholarship (pp. 37-52). Switzerland: Springer International Publishing.

Rozkwitalska, M. \& Basinska, B.A. (2015a). Job satisfaction in the multicultural environment of multinational corporations. Baltic Journal of Management, 10(3), 366-387.

Rozkwitalska, M. \& Basinska, B.A. (2015b). Thriving in multicultural work settings. In: D. Vrontis, Y. Weber \& E. Tsoukatos (eds.), Conference Readings Book Proceedings. Innovation, Entrepreneurship and Sustainable Value Chain in a Dynamic Environment (pp. 1897-1910). September 16-18, 2015, Verona: EuroMed Press. Retrieved from

Rozkwitalska, M. \& Basinska, B.A. (2016a). Positive psychological capital enhances thriving in the multicultural work environment of multinational corporations. In: D. Vrontis, Y. Weber \& E. Tsoukatos (eds.), Innovation, Entrepreneurship and Digital Ecosystems (pp. 1565-1576). Warsaw: EuroMed Press.

Rozkwitalska, M. \& Basinska, B.A. (2016b). Thriving and job satisfaction in multicultural environments of MNCs. In: I. Simberova, O. Zizlavsky \& F. Milichovsky (eds.), SMART and Efficient Economy: Preparation for the Future Innovative Economy. Proceedings of Selected Papers (pp. 111-119). Brno: Brno University of Technology. Retrieved from http://www.icem.lt/ public/icem/Proceeding of selected papers_2016_Final.pdf (access 1.03.2017).

Rozkwitalska, M., Basinska, B.A., Chmielecki, M., Przytuła, S. \& Sułkowski, Ł. (2016). Intercultural interactions at multinational corporations' workplace. Journal of Positive Management, 7(1), 3-31.

Rozkwitalska, M., Chmielecki, M., Przytula, S., Sulkowski, L. \& Basinska, B.A. (2017). Intercultural interactions in multinational subsidiaries: Employee accounts 
of "the dark side" and "the bright side" of intercultural contacts. Baltic Journal of Management, 2(12), 214-239.

Schaufeli, W., Bakker, A. \& Salanova, M. (2006). The measurement of work engagement with a short questionnaire a cross-national study. Educational and Psychological Measurement, 66(4), 701-716.

Spreitzer, G.M. \& Sutcliffe, K.M. (2007). Thriving in organizations. In: D.L. Nelson \& C.L. Cooper (eds.), Positive Organizational Behavior (pp. 74-75). London, Thousand Oaks New Delhi: Sage Publications.

Spreitzer, G., Sutcliffe, K., Dutton, J., Sonenshein, S. \& Grant, A.M. (2005). A socially embedded model of thriving at work. Organization Science, 16(5), 537-549. https://doi.org/10.1287/orsc. 1050.0153

Stahl, G.K., Mäkelä, K., Zander, L. \& Maznevski, M.L. (2010). A look at the bright side of multicultural team diversity. Scandinavian Journal of Management, 26(4), 439-447.

Stahl, G.K., Maznevski, M.L., Voigt, A. \& Jonsen, K. (2009). Unraveling the effects of cultural diversity in teams: A meta-analysis of research on multicultural work groups. Journal of International Business Studies, 41(4), 690-709.

Stahl, G.K. \& Tung, R.L. (2014). Towards a more balanced treatment of culture in international business studies: The need for positive cross-cultural scholarship. Journal of International Business Studies, 1-24.

Vandewalle, D. (1997). Development and validation of a Work Domain Goal Orientation Instrument. Educational and Psychological Measurement, 57(6), 995-1015.

Wallace, J.C., Butts, M.M., Johnson, P.D., Stevens, F.G. \& Smith, M.B. (2013). A multilevel model of employee innovation understanding the effects of regulatory focus, thriving, and employee involvement climate. Journal of Management, 42(4), 982-1004.

Whetten, D.A. (2008). An examination of the interface between context and theory applied to the study of Chinese organizations. Management and Organization Review, 5(1), 29-55. 


\section{PROSPEROWANIE A MONO- I WIELOKULTUROWY KONTEKST ORGANIZACJI}

Tło badań. Prosperowanie, składające się z uczenia się i witalności, przyczynia się do powstawania wielu pozytywnych efektów dla organizacji. Jednak brakuje badań na temat prosperowania będącego skutkiem społecznych interakcji, które porównywałyby dwa typy kontekstu organizacyjnego, tj. mono- i wielokulturowy.

Cel badań. Celem artykułu jest porównanie poziomu prosperowania (tj. uczenia się i witalności) w kontekście mono- i wielokulturowym pracy. Autorka zakłada, że wielokulturowe środowisko pracy tworzy unikalne wymagania, które sprzyjaja prosperowaniu w większym stopniu niż wymagania kreowane przez monokulturowe środowisko pracy.

Metodologia. Badania poprzeczne przeprowadzono w firmach krajowych i korporacjach wielonarodowych, które reprezentuja odpowiednio mono- i wielokulturowe środowiska pracy. Próby składały się z 259 pracowników mających tylko interakcje monokulturowe oraz 238 jednostek zaangażowanych w interakcje międzykulturowe.

Kluczowe wnioski. Badania pokazały, że osoby zatrudnione w organizacjach wielokulturowych doświadczały wyższego poziomu prosperowania niż pracownicy organizacji monokulturowych. Wyniki potwierdzaja, że kontakty społeczne, włączając interakcje międzykulturowe, są konieczne, by pobudzać prosperowanie w organizacjach. Artykuł dotyczy pozytywnego rozwoju jednostek, wnosi więc wkład w pozytywny nurt zarządzania.

Słowa kluczowe: uczenie się, interakcje międzykulturowe, interakcje monokulturowe, witalność, doświadczenie międzynarodowe. 